\title{
Effect of thong style flip-flops on children's midfoot motion during gait
}

\author{
Angus Chard ${ }^{1 *}$, Andrew Greene ${ }^{1}$, Adrienne Hunt ${ }^{1}$, Benedicte Vanwanseele ${ }^{2}$, Richard Smith ${ }^{1}$ \\ From 3rd Congress of the International Foot and Ankle Biomechanics Community \\ Sydney, Australia. 11-13 April 2012
}

\section{Background}

Thong style flip-flop footwear (TH) and sandals are the preferred footwear of $22 \%$ of Australian children, however little is known about the effects of wearing $\mathrm{TH}$ on the growing child [1]. Previous research has shown TH reduces children's hallux dorsiflexion prior to contact during walking and jogging and at toe-off whilst jogging [2]. Adult studies have shown $\mathrm{TH}$ alters barefoot motion with reduced eversion [3] and reduce peak plantar-pressure at the hallux, metatarsal heads and calcaneus [4]. The influence of TH on children's midfoot kinematics may have important ramifications for children's developing feet. This study aims to describe the effect of $\mathrm{TH}$ on children's midfoot motion during walking and jogging.

\section{Materials and methods}

Seven healthy children, mean age $10.47 \pm 1.98$ years were recruited from Sydney Australia. Participants conducted five walking trials and five jogging trials while barefoot and wearing $\mathrm{TH}$ in random order. A fourteen camera, three-dimensional motion analysis system was used to collect kinematic data. Markers located at navicular, first

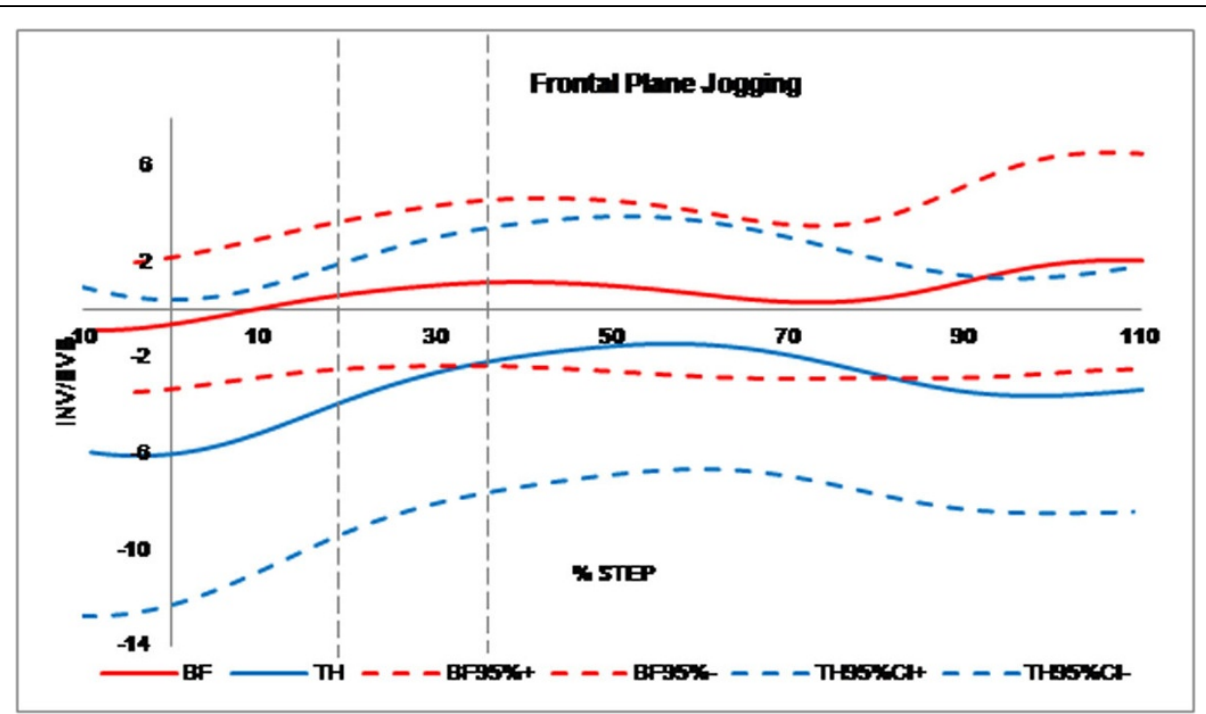

Figure 1 Mean midfoot frontal plane range of motion data from $-10 \%$ to $+10 \%$ of the stance phase of gait for barefoot ( red) and thongs (blue), including $\pm 95 \% \mathrm{Cl}$. Contact, midstance and propulsion phases are defined by vertical dashed lines.

\footnotetext{
* Correspondence: bcha8278@uni.sydney.edu.au

'Exercise and Sport Science, University of Sydney, Sydney, NSW, 1825

Australia

Full list of author information is available at the end of the article
}

(c) 2012 Chard et al; licensee BioMed Central Ltd. This is an Open Access article distributed under the terms of the Creative Commons 
and fifth metatarsal phalangeal joints, hallux and a rearfoot wand, defined three foot segments: rearfoot, forefoot and hallux. The midfoot joint was defined as the articulation between rearfoot and forefoot segments.

\section{Results}

A repeated measure ANOVA found no significant effect of thongs while walking when compared to barefoot although a trend was seen towards a more dorsiflexed, everted and abducted midfoot. A significant effect of $\mathrm{TH}$ while jogging was seen during propulsion in the frontal plane (Figure 1) with the forefoot more inverted $(\mathrm{P}=0.016)$ in the $\mathrm{TH}$ condition $-4.5 \pm 6.3 \mathrm{SD}$ compared with BF $3.8 \pm 5.0 \mathrm{SD}$ at toe-off, while sagittal and transverse planes were not significantly different.

\section{Conclusions}

During the propulsive phase significantly greater forefoot inversion was seen while jogging wearing $\mathrm{TH}$. Results reported are early findings of an ongoing project. With greater participant numbers the trends of greater forefoot extension, eversion and abduction while walking may become significant.

\section{Author details}

${ }^{1}$ Exercise and Sport Science, University of Sydney, Sydney, NSW, 1825 Australia. ${ }^{2}$ Department of Biomedical Kinesiology, Katholieke Universiteit Bus 50053000 Leuven, Belgium.

Published: 10 April 2012

\section{References}

1. Penkala S: Footwear choices for children: knowledge, application and relationships to health outcomes. Sydney, University of Sydney.

2. Chard A, Smith R, et al: Effect Thong Style Flip-Flop Footwear On Children's Hallux Sagittal Plane Motion During Gait. ISBS Brussels, Belgium; 2011.

3. Shroyer J, et al: Effect of Various Thong Flip-flps on Pronation and Eversion During Midstance. ACSM Confrence Baltimore, Maryland, USA; 2010.

4. Carl TJ, Barrett SL: Computerized analysis of plantar pressure variation in flip-flops, athletic shoes, and bare feet. J Am Podiatr Med Assoc 2008, 98:374-378,

doi:10.1186/1757-1146-5-S1-019

Cite this article as: Chard et al:: Effect of thong style flip-flops on children's midfoot motion during gait. Journal of Foot and Ankle Research 2012 5(Suppl 1):019

\section{Submit your next manuscript to BioMed Central} and take full advantage of:

- Convenient online submission

- Thorough peer review

- No space constraints or color figure charges

- Immediate publication on acceptance

- Inclusion in PubMed, CAS, Scopus and Google Scholar

- Research which is freely available for redistribution

Submit your manuscript at www.biomedcentral.com/submit 